\title{
The History and Current Development of Indigenous People Movements in Indonesia
}

\author{
Ahmad Ridha Mubarak ${ }^{1}$, Rabiatul Adawiah ${ }^{2}$ \\ Universitas Gadjah Mada Yogyakarta ${ }^{12}$ \\ ahmadridha92@mail.ugm.ac.id ${ }^{1}$,rabiatul.a@mail.ugm.ac.id ${ }^{2}$
}

\begin{abstract}
Riwayat Jurnal
Artikel diterima: 7 Juni 2021

Artikel direvisi: 23 Juni 2021

Artikel disetujui: 25 Juni 2021
\end{abstract}

Kata Kunci:
Kebebasan Beragama,
Hak Asasi Manusia
Tanah Adat,
Gerakan Masyarakat
Adat

\section{Abstrak}

Tulisan ini didasarkan pada suatu arguman bahwa diskriminasi terhadap masyarakat adat merupakan fakta dinamika interpretasi kebijakan yang ada. Maka dari itu kehadiran Gerakan mayarakat adat seperti AMAN (Aliansi Masyarakat Adat Nusantara) menawarkan solusi atas pelanggaran terhadap hak-hak masyarakat adat, serta sebagai wadah diskusi tentang kemungkinan ancamanancaman lainnya. Tujuan dari gerakan masyarakat adat adalah menegakkan kebebasan beragama untuk mempromosikan kesetaraan hak-hak masyarakat adat, khususnya terkait pentingya tanah adat bagi mereka. Dalam satu sisi, negara mengakui dan menghargai hak-hak masyarakat adat, namun di sisi lain mereka dituntut dengan persyaratan yang sulit dalam mewujudkan hakhak mereka.

\section{Keyword:}

Religious Freedom, Human Rights, Customary Land, Indigenous People Movement

Abstract
This paper is based on an argument that discrimination against
indigenous religion is a fact of the dynamics of policy
interpretations. Therefore, the presence of indigenous people
movements such as AMAN (Aliansi Masyarakat Adat
Nusantara), offers solutions for indigenous rights' violations, and
it also serves as a place for discussion on existing and possible
threats upon indigenous communities. The indigenous people
movements aim to establish religious freedom as a means to
promote indigenous religion rights, particularly the importance of
customary land. On the one hand, the state recognizes the rights of
indigenous people, but, on the other hand they are prosecuted with
hard conditions in realizing their rights. This study uses a
descriptive method that describes, explains and analyze the
situation and conditions experienced by Indigenous religion and
adat movement to promote indigenous rights. This study found


that AMAN as one of the indigenous people movement was established in order to advocate and defend the rights of indigenous people.

\section{Introduction}

Indigenous religions have lost their rights and religious freedom; this is related to their land rights. However, land for indigenous peoples is part of the most important identity that marks its existence. Since the 1998 reformation, many laws and regulations have been issued to recognize the existence and rights of indigenous people's lands, natural resources and other basic rights (Arizona, 2013), but the principles are not actualized in legal norms as a condition for the realization of legal goals, namely justice. The portrait of the law, which only pays attention to the principle of no intolerance without accommodating the principle of equality, has actually become the beginning of discrimination and intolerance (Armiwulan, 2015).

AMAN (Aliansi Masyarakat Adat Nusantara) movement reported that during 2020 there were 40 cases of discrimination or intolerance against indigenous peoples, most of these cases had happened in previous years, but continued to happen because it never got a solution. This indicates that discrimination is an everlasting matter for Indigenous religion. In addition, the involvement of indigenous movements such as AMAN aims to establish religious freedom as a means to promote indigenous religious rights, particularly the importance of indigenous territories. They have surveyed over ten million hectares of potential land claims, listed claims into online interactive maps, and otherwise stated that claims amount to over 40 million hectares of national-forest (Fisher, 2019).

The problems experienced by indigenous peoples have given the impression that they are not citizens who have rights that are actually guaranteed in the constitution (Arizona, 2013). This is a disaster for indigenous religious groups. In another context, a similar point was made by Makau wa Mutua (1999) in Limitations on Religious Rights: Problematizing Religious Freedom in Africa and America that addressed human rights, constitutional, and other legal bases for religious freedom and the protection of indigenous religions in Africa.

So far, studies on discrimination against indigenous religions have tended to analyze the indigenous religion paradigm, reinterpretation religious practice, self-identification of indigenous people and articulating indigenous religion. A study at articulating indigenous religion shows that articulation is not just a connection but a process of simplification, boundary-making as well as creating connections (Slack, 1996). In addition, Li (2000) uses this theory to demonstrate how certain groups in Indonesia come to identify themselves as 
indigenous during moments at which global and local agendas have been con-joined in a common purpose, and presented within a common discursive frame, thus realigning the ways they connect to the nation, the government, and their own, unique tribal place, is the contingent products of agency and the cultural and political work of articulation.

Apart from previous research, this paper aims to complete the subjective dimension in the analysis of AMAN's involvement as an umbrella that protects Indigenous people's rights. Equally important, this paper maps out the forms or manifestations of discrimination on the rights of indigenous people's lands, as well as analyzes the factors or conditions that cause discrimination. The answer to this question is a subject that allows religious freedom to be understood as a means to promote indigenous religious rights and the importance of land for indigenous religion.

This paper is based on an argument that discrimination against indigenous religion is a fact of the dynamics of existing policy interpretations. Therefore, the presence of indigenous people movements such as AMAN, offers solutions for indigenous rights' violations, and it also serves as a place for discussion on existing and possible threats upon indigenous communities.

\section{Research Methodology}

This writing is a descriptive analysis that describes, explains and analyzes the situation and conditions experienced by Indigenous Religions and adat movements to promote indigenous land rights. It is due to the fact that the discourse on discrimination against indigenous people has been, is temporary, and will continue to take place in this country, as long as their status and rights have not been officially and fully guaranteed by law and implemented throughout the territory of the Unitary State of the Republic of Indonesia.

In line with that, the data needed to answer these questions is secondary data obtained from relevant literature, including textbooks, journal articles, documentation, research institute data and related agency data. One major factor of utilizing these data is the regulations on Covid-19, which limit the access to experiences of live subjects, including the indigenous communities and the members of adat movements.

\section{Literature Review}


This paper concerns about the effort of adat movements in advertising equal religious rights for indigenous communities in Indonesia. The following section discusses scholars' works with regard to three main variables that are examined in this paper - that is, religious freedom and human rights, the importance of land, and indigenous people movements.

\subsection{Religious Freedom and Human Rights}

In 1948, the United Nations issued the Universal Declaration of Human Rights (UDHR). Article 2 suggests that "Everyone is entitled to all rights and freedoms set forth in this Declaration without distinction of any kind, such as race, colour, sex, language, religion, and political or other opinion, national or social origin, property, birth or other status". In another article, article 18, it is said that "Everyone has the right to freedom of thought, conscience, and religion; this right includes freedom to change his religion or belief, and freedom, either alone or in community with others and in public or private, to manifest his religion or belief in teaching, practice, worship, and observance". In his article, Limitations on Religious Rights: Problematizing Religious Freedom in the African Context, wa Mutua argues that article 18 provides religious freedom for everyone and prohibits the use of force to have others join certain religions (wa Mutua, 1999). His research also shows how European missionaries and Arab Muslims converted people of Africa to Christianity and Islam due to their notion of being the people of "truth". These two religions contributed to the marginalization and destruction of indigenous rituals and ceremonies that had long been performed. Reinforcing the concept of human rights is necessary to decline such religious violations. His provision is to look at and understand cultures and religions from the lens of human rights movement. Though it suggests religions to be open to new ideas and challenges forms other traditions, religions should also offer protection for other believers without coercion to adopt their ideologies.

The second variable, customary land, is inseparable from the first feature. At the very heart of religion is worship. In indigenous context, worship often includes their customary land. What is meant by land is a sacred place, including, land, lake, river, or any particular "subject" on their land such as trees and rocks. The availability to access their land equals to religious freedom, one of the main concerns of human rights discourses. Oftentimes, their land vanishes due to what so-called humans' needs, which is interchangeable with the term humans' greed. Another issue lies within the position of the land itself which is sometimes situated under the government's supervision, which Collins discusses in his piece, Sacred Sites and Religious Freedom on Government Land (Collins, 2003). He adds that when a sacred land belongs to an indigenous community, 
they own full authority towards it. On contrast, when a sacred land belongs to the government or a private party, their authority is limited or even absent. He examines the success of four tribes in four nations in proving the importance and the meaning of their sacred sites to them - that is, the Maori in New Zealand, the Aboriginal people in Australia, the Indians in the United States, and the Inuit people in Canada. In their legal constitutions, an agreement was difficult to reach as the judges made their decisions and justifications under the notion of secularism where religious claims were less visible. The action was then brought into political sectors where religious claims were more possible. Hence, indigenous religions obtained their rights on their sacred sites with the help from New Zealand's Resource Management Act, Australia's Aboriginal Heritage Act, American RFRAs, and the Canadian Heritage Act.

Trope in his article, Protecting Native American Sacred Sites and Religious Freedom, elaborates that maintaining relationship with natural world, in this sense their sacred lands, is the true religious freedom for traditional Indians in America. Yet in most cases, their lands are subject to modern development. Construction of roads, for instance, contributes to the demolition of what used to be sacred spaces for them. He adds that their needs are incompatible with those of modernity, or simply the modern perspective disregards the traditional views on land. The issue was then reconciled after several meetings which involved Indian tribes, organizations and traditional religious practitioners, and governmental employees. Together they proposed a new legislation that allowed indigenous communities to participate in every matter concerning their lands. Such participation means legal action in terms of policy making and dialogue with the government in every governmental action that threatens their lands posed by modern construction.

\subsection{The importance of Land}

Another work by Larson, Holy Water and Human Rights: Indigenous Peoples' Religious-Rights Claims to Water Resources, strengthens the argument of the relation between land and human rights for indigenous people. Many indigenous communities possess a spiritual relationship with their lands and rivers. The most profound examination he provides in his piece is that a religious-rights-based approach to the human right to water for indigenous communities produces several advantages. First, it helps indigenous communities advertise sustainable water management or traditional 
ecological knowledge (TEK) that is represented in their ceremonies and teachings, which have been handed down from generation to generation. Second, their TEK might contribute to science without them knowing. The Altaians tribe, for instance, opposed the construction of a dam on their river, the Katun River, due to their spiritual connection with it. Scientists later discovered that building a dam would put particular fish species and medical plants in danger. However, religious beliefs could also contribute to the destruction of environment as portrayed in, for instance, the construction of religious stone statues in Easter Island, which deforested and depopulated the island. It also provides political basis for indigenous communities to be independent and selfgovernment. Today water resources are extracted and exploited for commercial purposes. It is amusing that even to drink humans need to pay certain amount of money. The success of the Ogoni people, the Kalahari Bushmen, and the Awas Tingni, in securing their rights to their water is an example to counter this phenomenon - that is, water is not to be contested, but to be preserved.

The notion of establishing equal rights for indigenous communities has led to the birth of indigenous people movements. These movements consist of the indigenous people themselves and those who stand by them voluntarily. Hodgson's article, Comparative Perspectives on the Indigenous Rights Movement in Africa and The Americas, compiles and analyzes the dynamics of indigenous rights movements in both continents (Hodgson, 2002). In the Americas, legal rights and protection have been given to most indigenous communities, yet the struggle to maintain such accomplishment seems far from an end. Brazilian Indians had actually been granted protection and legal rights until the new policy forced them to revise their images and identities. It encouraged any Indians belonging to local parties to advocate the nation instead of their own kinds. This was due to the claim, which was made by Brazilian politicians and advertised to public by the media, that the Indians had become pawns of foreign parties, which wished to exploit the natural resources. The Alaskan natives were utilized as a political tool by timber clearing and pulp production companies to achieve their goals. They helped the locals to regain their lands only to manipulate the government's restriction of timber harvesting on state lands. Since the lands no longer belonged to the state, they faced almost no problems to exploit the natural resources.

On contrary, the indigenous people movements in Africa were born to help them gain recognition from their own states. Pan-San indigenous movement in southern Africa was established to challenge the international model of indigenous, which separated 
"incorporated San" from "segregated San". The latter was easily recognized due to being similar to other indigenous, while the former was issued not to meet the international standard; thus, their rights were not granted. In northern Tanzania, local tribes such as Maasai, Barabaig, and other hunter-gather groups were prohibited to form alliances by the state, the donors, and even the transnational indigenous rights movement. The problem of representative was one of the main contributions to this arising difficulty.

\subsection{Indigenous People Movement}

In Indonesian context, Davidson and Henley's work, The Revival of Tradition in Indonesian Politics: The Deployment of Adat from Colonialism to Indigenism, examines four major factors leading to the revival of indigenous people (adat) movements (Davidson \& Henley, 2007). First, they were influenced by international movements such as International Working Group on Indigenous Affairs (IWGIA), survival International, and Cultural Survival. Second, the urge to release from the pressure and oppression of the New Order government came to surface. The authoritarian government emphasized the notion of Pancasila, particularly the first tenet; therefore, any religion which did not fit the criteria suffered from recognition, including indigenous religions. Third, people were offered opportunities and exigencies of reformasi. This period marked the beginning of full democracy in Indonesia. The most notable adat movement, Aliansi Masyarakat Adat Nusantara (AMAN), was established in this era in 1999. It aims to offer solutions for indigenous rights to the government and to accommodate discussion on current or possible threats upon indigenous communities such as recognition and land extinction. Last, history records that adat played a significant role in Indonesian politics since the beginning of nationalism in the early twentieth century. Today a lot of other adat movements exist with similar main pursuit - that is, to support equal rights for indigenous communities by, in particular, demanding authority over customary land.

\section{$4 \quad$ Findings and Discussion}

\subsection{Indigenous Customary Land's Expropriation}

Since the beginning of the independence of Indonesia, indigenous communities have suffered from recognition, even during the colonial period. Thus, it results in discrimination - that is, rights as citizens will only be granted when they belong to the recognized religions. Such discrimination takes various forms such as marriage registration, access to public services, and property or land's seizure. To avoid wide, 
myriad discussions, this paper is limited to the invasion of indigenous people's lands and how the government contributes to it.

In many parts of Indonesia, natural resources are extracted by palm oil corporations and mining companies. Oftentimes, the extraction, or exploitation to be precise, is done on indigenous people's territories. In Kalimantan, for instance, palm trees are grown everywhere on most of the island's lands, including the Dayak's lands (Davidson \& Henley, 2007). In so doing, an open field is needed - that is, the trees or the forests need cutting down. The logs are then produced for various purposes, including house construction and furniture. Only then the palm trees can be planted; however, palm trees leave negative impact to the environment. They absorb water greatly that they dry up the nearby stream or water sources. Palm trees can only fruit for some couple of years, so they need to be cut down and burnt after they are no longer productive. The Kendheng people in Central Java and the Mollos in East Nusa Tenggara experience similar matter (Maarif, 2019). The cement company running in the Kendhengs' environment harms their mountain and karst ecosystem that they have been preserving since their ancestors did. The Mollos' lands were exploited by marble mining factories which surely affected their religious life.

The most current expropriation on indigenous lands occurs during the pandemic. AMAN estimated around 1448 hectares of rainforest in Papua vanished from January to May last year (AMAN, 2020). In September the same year, the Rakyat Penunggu people in North Sumatra were invaded by heavy equipment which was used to extract their resources. The Besipae people were forced to leave their lands since the local government would use it for livestock, plantation, and tourism purpose. Similarly, the Laman Kinipan people in Central Kalimantan were expelled from their houses, and their farms were destroyed by one of the palm oil companies. Six of them who strongly defended their lands were incarcerated, including the local leader who worked for the government. In sum, the indigenous right upon their lands is yet to be a core issue they and the adat movements are struggling for no matter what the condition is.

The expropriation of indigenous people's lands is suggested to be a response to modernity. Modern lifestyle requires modern people to adjust with new needs that did not exist in the previous era such as shampoo, toothpaste, and instant foods, which contain palm oil in them. Without these items, people would feel their daily needs are somewhat lacking. Utilizing products of nature, as how indigenous people always do, forces modern people to reconsider the possible danger or threat of such products to their 
bodies since nature is now polluted. This also applies to indigenous people. If they continue to depend on natural resources alone, their lives are in danger. For this reason, companies are able to convince governments and local tribes that what they are doing is right. However, what actually occurs is competition among companies to be the dominant, resulting in the extinction of natural resources, including indigenous lands.

Owing to this cause, the adat movement like AMAN fights for the indigenous rights over their customary lands. Indigenous people are famous or their capability of preserving their environment though some might also contribute to destruction. The Dayaks have always depended on their lands as sources of daily needs and spiritual needs. The Dayak Bahau, for instance, cultivate their hills to grow crops not only for themselves but also and the animals living in their environment. This should be preceded by certain rituals where they give offerings to their land's protectors. The Dayak Meratus who reside in the Meratus mountains in South Kalimantan also depend on their land and forest as the sources where they could survive and fulfill their needs. For ages, this tribe has practiced agricultural systems to survive. The Kendheng people have an intimate relationship with their mountain which they refer to as their identity; while the Mollos identify their clan names by referring to stones of mountains (Maarif, 2019).

During the pandemic, land is the only source for the Rakyat Penunggu people to survive. They grow rice, and other plants just enough to feed their kind. Likewise, the Besipae people consider their land as a conservation place better known as Nais Kio, where they conserve their indigenous traditions and knowledge which they inherit from their ancestors for ages. Ideally, when one wishes to use something, they should get permission from the owner. Companies and corporations claim that they have received legal permission from the government, but the government should never claim possession of lands just because they geographically stand on their territories. They should discuss it with the "true" owner, the indigenous people. They ought to be included in policy-making with regard to land's extraction. A company wishing to run on indigenous land should respect the local traditions. In most Dayak traditions, for instance, one shall return to nature what they take from it. Thus, should one cut down trees to farm, they should replant what they cut after they harvest the crops.

Recently, AMAN problematizes the new revised constitutional law, UU No. 3 Tahun 2020, concerning minerals and coals (AMAN, 2020). First, the temporary 
permission (Kontrak Karya) will be automatically renewed one expired. AMAN believes that contract renewal needs to consider the possible environmental impact. Second, the local government's authority is declined; thus full authority towards coal and mining companies is the central government's responsibility. It removes the local government's supervision, law enforcement, and providing administrative sanctions in mining sectors. Third, it allows mining companies to run their own laws and policies and even expand their territories. Therefore, should indigenous communities wish to protest, the local government cannot facilitate them.

\subsection{State Funds the Expropriation of Customary Land}

This paper maps out the forms or manifestations of discrimination against indigenous religions' lands, based on what AMAN has explained that the ratification of presidential regulation (Perpres) no. 66 of 2020 in lieu of Presidential Decree No. 102 of 2012 concerning funding for land acquisition for development in the public interest in the context of implementing national strategic projects deserves to be questioned formally and materially. As a Presidential Decree that was born in the midst of the COVID-19 pandemic situation, public participation in its formulation did not occur, even though this is an important requirement in the process of forming legislation.

Before this Presidential Regulation was issued, the process of recognizing and protecting indigenous people and their rights to their territories was held hostage through various overlapping regulations. It is seen from the president's yell for solidarity of indigenous people to face the threat of food crisis, such as "overcoming the food crisis". Yet, it can only be assumed if farmers and indigenous people control and freely cultivate lands in customary areas to anticipate food crisis, which describes the discontinuity of ideas in the midst of weak protection which will have implications for the faster process of expropriation of customary land.

Based on data from the Ministry of Environment and Forestry's Directorate General of Planning (July, 2017), out of a total of 122 million hectares of forest areas that had been designated, an area of 87 million hectares or $86.80 \%$ had been designated as permanent forest areas. This means that less than $14 \%$ of forests, whose stages were still being appointed, were subject to conflicts which could be resolved through the mechanism regulated in Presidential Decree 88/2017. From the analysis of AMAN (2017), it was found that there were at least 1.62 million hectares spreading over 609 indigenous communities that were threatened with resettlement because they were in conservation areas. Moreover, with the enactment of Presidential Decree No. 66 of 2020, 
the threat of resettlement is getting real. It forces displacement which is legitimized by laws and regulations under the guise of national strategic development.

The expropriation case of customary land of the Pubabu-bisapae people has occurred in recent years. In 2020 the East Nusa Tenggara provincial government led directly by the Governor stated that the land and forest belonged to the East Nusa Tenggara provincial government. There was an invitation to socialize the government's plan for the development of the Basipae cattle lands, but this was not carried out because it was refused by Pubabu-bisapae. However, this did not reduce the government's decision to evict the lands belonging to the Perbabu-bisapae. The government even made a statement in which the community had agreed to be relocated.

During the incident, the government brought a team consisting of the Police, the Mobile Brigade (Korps BRIMOB), the Municipal Police (SATPOL PP) and the Indonesian National Armed Forces (TNI). The community tried to block and put up a fight. However, the government team succeeded in evicting 3 families who lived in a building that the government claimed as their assets. Their belongings were forcibly removed and then the team fenced the area with police lines.

Based on the existing case, AMAN stated that the position that the seizure of customary land in the name of national strategic project development resulted in conflict and impoverishment for indigenous people based on the Presidential Regulation needed to be revoked. They urged the president and the Peoples' Representative Council of Indonesia (DPR RI) to immediately ratify RUU into UU that provides a comprehensive process of recognition, protection and fulfillment of indigenous people's rights.

\section{Conclusion}

Discrimination upon indigenous communities in Indonesia yet includes in a long-awaited list of the nation's problems to be solved, and one of the issues is their rights concerning their lands. Besides, society get down the cases of Indigenous people only in their recognition. One of the most important findings from this paper is that AMAN as one of the indigenous people or adat movements was established in order to advocate and defend the rights of indigenous people. This is parallel to the vision of Indonesia, which can be concluded from the tenets of Pancasila - that is, to create a just and prosperous life for all the citizens, including indigenous people, so that they, in particular, could have authority over their lands and natural resources, 
socio-cultural-based life with regard to adat laws, and adat institutions to maintain their sustainability to continue to live as indigenous. This paper also suggests that the policies concerning indigenous people's rights can be realized to be in accordance with Indonesian Laws. Furthermore, there is an urge for further studies, whose attention values comparative aspects of the studied cases so that it allows the construction of deeper understanding.

\section{Bibliography}

Armiwulan, H. (2015). Diskriminasi Rasial dan Etnis Sebagai Persoalan Hukum dan Hak Asasi Manusia. Masalah-Masalah Hukum, 44(4), 493-502.

Arizona, Y. (2013). Masyarakat Adat dalam Kontestasi Pembaruan Hukum. In Makalah Seminar Pemberdayaan Sosial Komunitas Adat: Upaya Peningkatan Efektivitas Pemberdayaan KAT saat Ini dan Pengembangan ke Depan.

Baharamn, A. (2020, June 23). Negara Mendanai Perampasan Wilayah Adat. Aliansi Masyarakat Adat Nusantara. https://www.aman.or.id/2020/06/negara-mendanaiperampasan-wilayah-adat/.

Climate Change and the Adat Rituals of the Meratus Dayak Community. (2008). Down to Earth No. 76-77. https://www.downtoearth-indonesia.org/story/climate-change-andadat-rituals-meratus-dayak-community.

Collins, R. B. (2002). Sacred Sites and Religious Freedom on Government Land. U. Pa. J. Const. L., 5, 241.

Davidson, J., \& Henley, D. (Eds.). (2007). The Revival of Tradition in Indonesian Politics: The Deployment of Adat from Colonialism to Indigenism. Routledge.

Fisher, M. R. (2019). Beyond Recognition: Indigenous Land Rights and Changing Landscapes in Indonesia (Doctoral dissertation, University of Hawai'i at Manoa).

Heinämäki, L., \& Herrmann, T. (2017). Experiencing and Protecting Sacred Natural Sites of Sámi and other Indigenous Peoples. Cham: Springer Polar Sciences. Springer.

Hodgson, D. L. (2002). Introduction: Comparative Perspectives on the Indigenous Rights Movement in Africa and the Americas. American Anthropologist, 104(4), 1037-1049.

Kronologi Konflik Masyarakat Adat Pubabu dengan Pemerintah Provinsi Nusa Tenggara Timur. (2020, May 13). http://www.solidaritasperempuan.org/sub/wpcontent/uploads/2020/05/Kronologi-Konflik-Masyarakat-Pubabu-dengan-PemerintahNTT.pdf.

Larson, R. B. (2011). Holy Water and Human Rights: Indigenous Peoples' Religious-Rights Claims to Water Resources. Ariz. J. Envtl. L. \& Pol'y, 2, 81.

Li, T. M. (2000). Articulating Indigenous Identity in Indonesia: Resource Politics and the Tribal Slot. Comparative Studies in Society and History, 42(1), 149-179. 
Maarif, S. (2017). Pasang Surut Rekognisi Agama Leluhur dalam Politik Agama di Indonesia. CRCS UGM.

Maarif, S. (2019). Indigenous Religion Paradigm: Re-interpreting Religious Practices of Indigenous People. Journal of Studies in Philosophy.

Marín, G., \& Gamba, R. J. (2003). Acculturation and Changes in Cultural Values.

Niezen, R. (2003). The Origins of Indigenism: Human Rights and the Politics of Identity. Univ of California Press.

Resiliensi Masyarakat Adat di tengah Pandemi Covid-19: Agresi Pembangunan \& Krisis Hak Asasi Manusia (HAM). (2020). Catatan Akhir Tahun 2020 Aliansi Masyarakat Adat Nusantara.

Slack, J. D. (1996). The Theory and Method of Articulation in Cultural Studies. In Morley, D. and Chen, K-H. (Eds.) Stuart Hall: Critical Dialogues in Cultural Studies. London: Routledge. 112-127.

Trope, J. F. (1991). Protecting Native American Sacred Sites and Religious Freedom. Wicazo Sa Review, 53-55.

United Nations. (1948, December 10). Universal Declaration of Human Rights. https://www.un.org/en/about-us/universal-declaration-of-human-rights.

wa Mutua, M. (1999). Limitations on Religious Rights: Problematizing Religious Freedom in the African Context. Buff. Hum. Rts. L. Rev., 5, 75. 